\title{
Transnational networks and the adoption of model forests in Argentina
}

Redes transnacionales y la adopción de bosques modelos en Argentina*

RICARDO A. GUTIÉRREZ

Universidad Nacional de San Martín, Argentina

Consejo Nacional de Investigaciones Científicas y Técnicas, Argentina

ricardo.gutierrez@unsam.edu.ar.

\section{MÓNICA GABAY}

Universidad Nacional de San Martín, Argentina

Consejo Nacional de Investigaciones Científicas y Técnicas, Argentina

Secretaría de Ambiente y Desarrollo Sustentable, Argentina

monica.gabay@unsam.edu.ar

ISABELLAALCAÑIZ

University of Maryland, Estados Unidos

Ialcaniz@umd.edu

How are international environmental ideas adopted locally? We answer this question by examining the adoption and development of the model forest idea in Argentina since the late 1990s. The concept of model forest was born in Canada in 1991 as the brand name of a new national program aimed at promoting the building of local-level governance processes and arrangements for sustainable forest management. The idea soon started travelling worldwide thanks to the Canadian international cooperation agencies' initiatives and became a benchmark of UN programs. Argentina was an early adopter of the model forest idea: in 1996 the Argentine Secretariat for the Environment signed a letter of intent with the International Model Forest Network. As a result, six model forests formed throughout the country between 1998 and 2008. We argue that transnational networks of bureaucrats, advocates, and stakeholders help explain how natural resources governance programs travel across countries. We distinguish more technical-driven adoptions from societal-driven ones, as a function of existing levels of conflict. We expect technical-driven adoptions to take place in contexts of lower levels of conflict and societal-driven adoptions in contexts of higher levels of conflict. This paper is a first step in a broader project that compares the adoption and evolution of community-based forests in Latin America.

Articulo aceptado para su publicación el 4 de mayo de 2019. 


\section{Introduction}

How are international environmental programs adopted locally? We answer this question by examining the adoption of the model forest program in Argentina in the late 1990s. Model forests are community-managed woodlands that forge partnerships among community, private, and public stakeholders. We argue that transnational networks of bureaucrats and advocates help explain how natural resources governance programs travel between countries -or between international organizations (IOs) and countries. We distinguish more technical-driven adoptions from societal-driven ones, as a function of existing levels of conflict. For Argentina, a low-conflict case, bureaucrats in the Secretariat for the Environment were critical in presenting these community-based models as a way to manage sustainably the natural resources coming from the forest and minimize disputes with local stakeholders. The timing of the adoption in the late 1990s is explained by a decade characterized by significant trade reforms that helped push the agricultural frontier, which in turn explains an increased urgency to protect and conserve Argentina's forests.

The concept of model forest was born in Canada in 1991 as the brand name of a new national program aimed at promoting the building of locallevel governance processes and arrangements for sustainable forest management. The idea soon started travelling worldwide thanks to the Canadian international cooperation agencies' initiatives and became a benchmark of UN programs. Argentina was an early adopter of the model forest idea: in 1996 the Argentine Secretariat for the Environment signed a letter of intent with the International Model Forest Network. As a result, six model forests formed throughout the country between 1998 and 2008.

How did the model forest concept arrive to Argentina? How was it revised by national and subnational actors? Throughout the paper we discuss how the adoption and development of the model forest concept in Argentina was not connected to international cooperation projects or the expectation of accessing them (as was the case in other Latin American countries). Rather, critically at the national level, model forests were regarded by environmental bureaucrats as a policy instrument contributing to the improvement of peaceful forest governance, rural communities' livelihoods, and sustainable local development. At the local level, stakeholders and their motivations in partnering with national bureaucrats varied. In some cases, local communities saw the model forest as a way to advance their source of revenue; in others, municipal or provincial agents saw political advantages in supporting this concept. Twenty years after its adoption, the core structur- 
ing concepts of Argentine model forests are forest landscapes, territorial development, social inclusion and participatory governance.

This paper is a first step in a broader project that compares the adoption and evolution of community-based forests in Latin America. In the expanded project, we will focus on forest stakeholders' practices in landscape protection, water regulation, and biodiversity conservation in five communal forests varying from low to high conflict conditions in Argentina, Mexico, and Guatemala. Before embarking on a cross-national comparison, we examine the adoption process of community foresting in Argentina. The paper draws from the literature on policy networks in the adoption of conservation programs. It tracks the history of model forests in Argentina through archival research and process-tracing, revealing a causal narrative that explains the role of a transnational network of like-minded state professionals working in native forests conservation. The research especially benefited from one of the authors' direct involvement in the formation and working of model forests in Argentina.

How international environmental norms and concepts are adopted locally carry significant implications to the study of forest conservation and state capacity. Local conservation efforts increasingly rely on policy solutions first implemented elsewhere across the globe. Transnational networks of experts and advocates play critical roles in sharing novel concepts and the necessary know-how to implement them. Understanding how these programs travel across different environments will help facilitate international green norm diffusion. In the case at hand, the transnational network that was instrumental in the adoption of model forests in Argentina was made up of bureaucrats, advocates, and stakeholders from the Canadian Forest Service; the IberoAmerican Model Forests Network (RIABM); the United Nations Food and Agriculture Organization (FAO); the Argentine Directory of Forestry; and provinces and municipalities. Further, and as importantly, the study of model forest itself is relevant as there is an increasing body evidence that communitybased foresting minimizes conflict and prevents deforestation (Nygren, 2005; Agrawal and Chhatre, 2006; Perez-Verdin et al., 2009).

The paper proceeds as follows. First, we discuss briefly the role of transnational networks in domestic norm adoption in environmental conservation. Next, we trace the process that goes from the emergence of the idea in Canada in 1991 until its adoption in Argentina in 1996 in order to understand why the Argentine environmental secretariat decided to adopt the idea and how the idea was amended by domestic actors. In the third section, we give an account of the development of three of the six Argentine model forests (Norte de Neuquén, San Pedro, and Tucumán) in order to pinpoint the main actors involved and their motivations to form a model forest. 
These three cases vary in levels of conflict, which allow us to test the influence of this contextual variable in the adoption of the model forest concept. In the last section, we take stock of the adoption process and summarize the main achievements and shortcomings of our three cases.

\section{The Role of Transnational Networks in Domestic Norm Adoption}

Inasmuch as traditional instruments of forest management have been ineffective in safeguarding the sustainability of these ecosystems against increasing anthropogenic pressures, greater attention has focused on community management models (Gibson et al., 2000; Campos et al., 2001; Terborgh and Peres, 2017). There is an emerging consensus among scholars and stakeholders that locally managed landscapes are successful mechanisms to protect the sustainable use of forests and ensure the subsistence of human populations (Gabay and Alam, 2017; Agrawal and Chhatre, 2006; McCarthy, 2006; Pagdee et al., 2006). One way in which these programs are adopted is through the work and advocacy of (trans)national networks (Alcañiz, 2016; Hadden and Seybert, 2016; Andonova et al., 2009).

Actors forge networks when they develop voluntary, reciprocal, and horizontal ties over time. When these actors have stakes in a particular policy area and exchange resources to advance their policy expertise, these become policy networks. That is, networks from which policy actors can derive technical information, know-how, and other resources. This kind of network has been identified as facilitating policy design, adoption, and implementation (Heclo, 1978; Haas, 1992; Sabatier and Jenkins-Smith, 1999; Carpenter, 2001; Schneider et al., 2003; Lubell, 2007; Scholz et al., 2008). A vast literature has pointed to the importance of policy networks in the adoption of environmental protections, especially those that include state stakeholders (Keck and Sikkink, 1999; Hochstetler and Keck, 2007; Andonova et al., 2009). Networks facilitate policy coordination, information sharing, and conflict resolution in environmental conservation (Berardo and Mazzalay, 2012; Hadden 2015). Further, they are likely to emerge in state structures where bureaucrats have high levels of technical expertise and specialization (Heclo, 1978; Carpenter, 2001; Alcañiz, 2016). Thus, we should expect international agencies and programs, such as the International Model Forest Network, to overlap and connect with domestic policy networks of bureaucrats with similar policy expertise.

We expect the influence of (trans)national networks of state experts to be greater and more technical in nature when we observe low-levels of societal conflict. As local social groups increase their stakeholder demands on 
government officials for a greater share of forest management, we expect the adoption of model forests to become more political. In high-conflict environments, we hypothesize a lesser role for state technocratic actors. We expect to be able to test these hypotheses in a future cross-national comparison, which will include Mexican and Central American cases of community-managed forests. Still, it should be noted that conflict levels vary across local contexts within a single country. Thus, we analyze within Argentina different MF cases with varying local settings.

\section{The Model Forest Concept in Argentina}

\subsection{Origins of the Model Forest concept}

Forestry and forest related activities account for a substantial part of Canadian economy, in addition to the importance of forest landscape's environmental goods and services. ${ }^{1}$ Back in 1991, Canadian forest sector experienced mounting conflicts between forest concessions and local forest dependent communities. At the international level, the situation of world's forests was rapidly deteriorating due to the acceleration of processes of degradation and deforestation.

Multilateral organizations and cooperation agencies actively promoted the concept of sustainable forest management, with the United Nations Food and Agriculture Organization fostering the development of national forest plans throughout the global south. Traditional forest policy instruments were ineffective to grant the sustainability of forest ecosystems undergoing increasing anthropic pressure. It was also necessary to address the growing public demand for transparency and public participation in decision making processes.

The Canadian Forest Service (CFS) turned this challenge into an opportunity to develop a new model of planning and management based on a bioregional platform devised to promote participatory sustainable forest management. The National Forest Strategy and Canada Forest Accord developed in the early 1990's reckon the need for sustainable forest management (SFM) to go beyond top-down solutions and to provide practical guidance for implementing SFM principles at the local level. Thus, the CFS created the innovative concept of model forest as «large-scale, living laboratories where people with an interest in the forest, supported by the most upto-date science and technology, could participate in decisions about how the forest could be sustainably managed» (Naysmith, 2003: 9). In 1991 the

\footnotetext{
See https://www.nrcan.gc.ca/forests/report/economy/16517 .Visited on April 17, 2019.
} 
CFS launched the first call for proposals for managing forest areas at landscape scale using the model forest Concept. The Canadian Model Forest Program was created in 1992, when Canada announced an International Model Forest Network (IMFN) initiative at the United Nations Conference on Environment and Development.

\subsection{Argentina adopts the «Model Forest» concept}

Native forests account for about $12 \%$ of Argentina's $2.791 .810 \mathrm{~km}^{2}$ land area. The processes of deforestation and degradation can be traced back to the arrival of the first Spanish «conquerors». However, starting in the late 1980's, the so-called Green Revolution accelerated changes in land use resulting in deforestation, degradation and fragmentation of forest ecosystems (FAO, 2005). Traditional policies and regulations were clearly not effective since this trend was not decelerating. In 1995, the federal Directorate of Forestry, based in the Argentine federal environmental authority, identified the model forest concept as an innovative tool to produce structural changes al local level that would foster sustainable development through SFM. The fact that Canada is a federal country, just like Argentina, was an incentive to consider the model forest approach.

In 1996, with support from the IMFN, the Directorate of Forestry organized the «First Workshop for the Argentine Model Forest Network» in the Province of Cordoba, with participants from all the forest regions. During the workshop, IMFN representatives conveyed the experience of Canadian and Mexican model forests, and discussed with the participants the applicability of the concept in the Argentine milieu. The result was the decision to implement this concept and the collective creation of an Argentine definition of a model forest as «an association of wills that consensually plan and manage sustainable development models for forest ecosystems. This model must improve the standard and quality of life of marginalized communities as a fundamental guideline» (SRIBM/SRNyAH-DB/PRODIA, 1996: 45). The workshop also produced a set of selection criteria for new model forest sites, incorporated in the guide for model forest proposals published by the Directorate of Forestry, as follows:

i. Representativeness in the bioregion;

ii. Presence of high ecosystem diversity;

iii. Inclusion of significant areas of recoverable ecosystems;

iv. Priority contribution to the maintenance of regional biological and cultural diversity; 
v. Legal framework;

vi. Degree of dependence of local communities from the forest resource;

vii. Realistic economic development base;

viii. Possibility of involvement of marginalized local population (indigenous communities, creole peasants);

ix. Stakeholder participation in the program design;

$\mathrm{x}$. Provincial and municipal governments commitment;

xi. Availability of support from the regional scientific - technological system.

In May 1996, Argentina signed a formal agreement with the IMFN in order to establish one Model forest per forest region. The Directorate of Forestry then set up the National Model Forest Program (NMFP) with the mission of promoting sustainable management of forest ecosystems based upon strategic alliances of key stakeholders and networking in order to contribute to the progress of the involved communities, considering social equity, local needs and global concerns. The National Model Forest Network (NMFN) was set up in 2001 and as of 2016 comprises six active Model forests and one under development (Figure 1, Table 1).

Table 1

Argentine Model forests

\begin{tabular}{|c|c|c|c|c|c|}
\hline $\begin{array}{l}\text { Model } \\
\text { forest }\end{array}$ & Status & $\begin{array}{l}\text { Forest } \\
\text { Region }\end{array}$ & $\begin{array}{c}\text { Area } \\
\text { (ha) }\end{array}$ & $\begin{array}{l}\text { Population } \\
\text { (hab.) }\end{array}$ & $\begin{array}{c}\text { Year of } \\
\text { affiliation }\end{array}$ \\
\hline Futaleufú & Active & $\begin{array}{c}\text { Bosque } \\
\text { Andino } \\
\text { Patagónico }\end{array}$ & 738,000 & 42,479 & 1998 \\
\hline Formoseño & Active & $\begin{array}{c}\text { Parque } \\
\text { Chaqueño }\end{array}$ & 800,000 & 45,000 & 2000 \\
\hline $\begin{array}{l}\text { North of } \\
\text { Neuquén }\end{array}$ & Active & $\begin{array}{c}\text { Bosque } \\
\text { Andino } \\
\text { Patagónico }\end{array}$ & $1,000,000$ & 27,182 & 2005 \\
\hline San Pedro & Active & $\begin{array}{l}\text { Paranaense } \\
\text { Rainforest }\end{array}$ & 443,514 & 31,050 & 2007 \\
\hline Tucumán & Active & $\begin{array}{l}\text { Selva } \\
\text { Tucumano } \\
\text { Boliviana } \\
\text { (Yungas) }\end{array}$ & 180,000 & 900,000 & 2008 \\
\hline Jujuy & Active & $\begin{array}{c}\text { Selva } \\
\text { Tucumano } \\
\text { Boliviana } \\
\text { (Yungas) }\end{array}$ & 433,500 & 100,000 & 2002 \\
\hline
\end{tabular}

Source: SAyDS, 2016. 
Figure 1

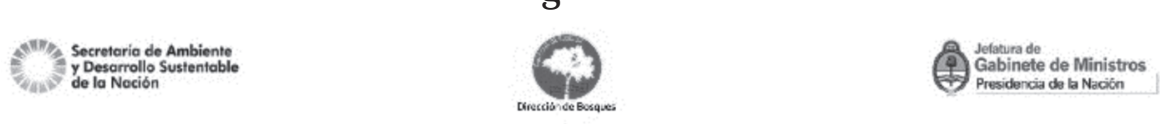

\section{Argentine Model Forests}

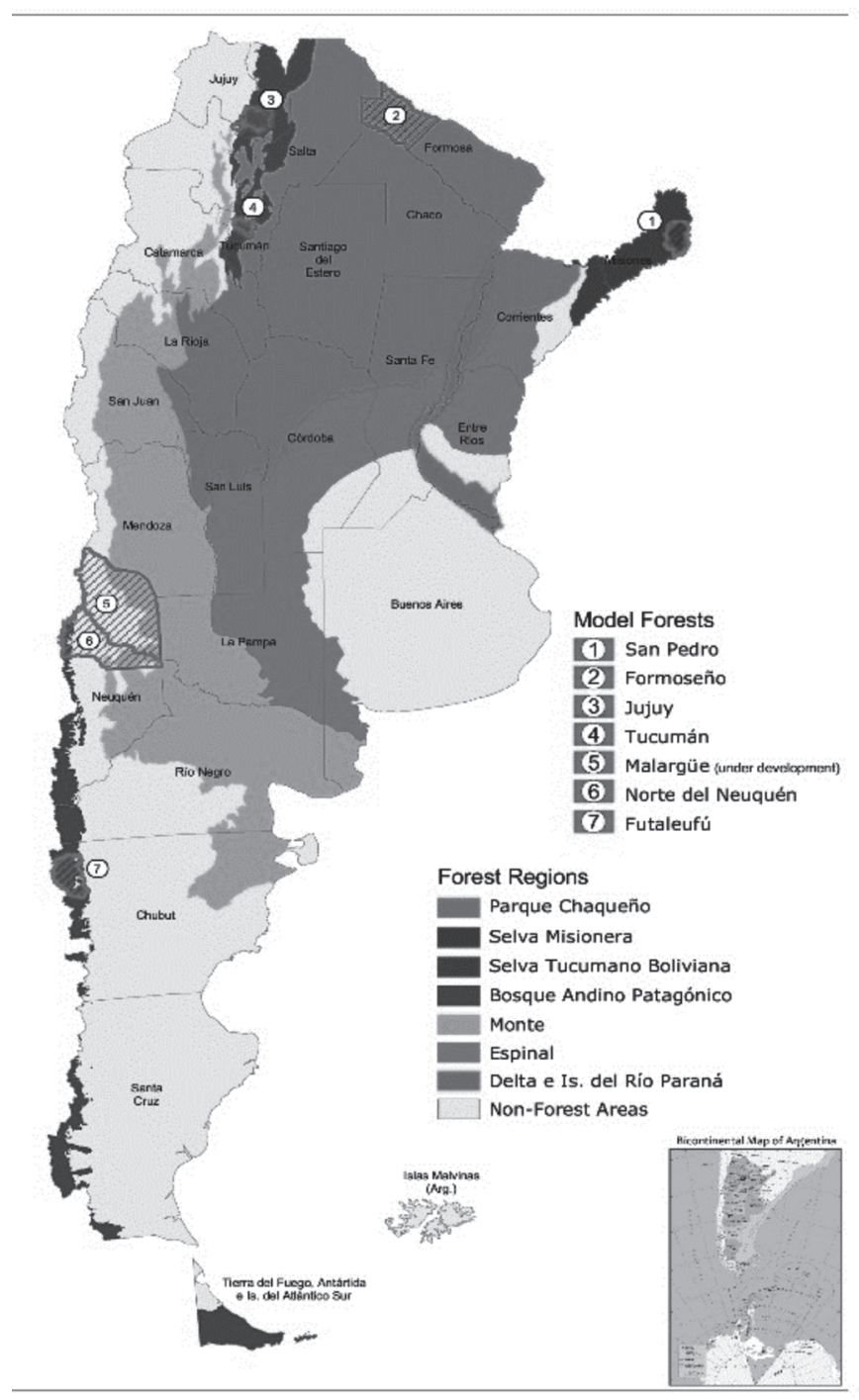

National Model Forest Network.

Source: «Programa Nacional de Bosques Modelo. Red Nacional de Bosques Modelo 2015», Dirección de Bosques, Secretaría de Ambientey Desarrollo Sustentable de la Nación. 
The NMFP takes into account a participatory approach to planning and management based upon the construction of multisector strategic partnerships involving stakeholders from the public and private sectors, civil society, grassroots organizations and academia. Model forests must base their action on a shared vision integrating common goals that contribute to local forest communities' development. The NMFN focuses on seven main topics, namely:

- Conservation and sustainable management of natural resources;

- Identification of opportunities and implementation of initiatives for the enhancing of sustainable livelihoods through the diversification of local production and valorization of forest related environmental goods and services;

- Capacity building through formal and non-formal education;

- Support of forest research for sustainable development;

- Traditional forest related knowledge;

- Design and implementation of participatory governance structures;

- Networking and knowledge management.

Model forest may also be regarded as network processes of planning and adaptive management with horizontal and vertical interactions among interested parties at the local, provincial and national levels. In contrast with traditional unidirectional models with top-down information flows, Model forests also encourage bottom-up information flows. Being participatory governance structures, model forests foster horizontal exchanges among their members and with local communities, as well as with other model forests and non-member organizations. These information flows enhance systemic learning of lessons of experiences and best practices.

\section{Three Cases of Argentine Model forests}

\subsection{North of Neuquén Model forest: Low Conflict and Technocratic-Driven Process}

North of Neuquén FM was created in 2007. Northern Neuquén forests belong to the Andean Patagonian forest region and are located at the northwestern border of the Argentine Patagonia and east of the Andes Mountains. The MF's total area is 1,500,000 hectares comprising territory of three province of Neuquén's departments: Minas, Chos Malal, and Norquín. It is 
home to several provincial protected areas with important reserves of native forests. A high percentage of the MF land is fiscal (66\% as of 2007) and part of it is open to communal pasture. The total population of Northern Neuquén MF is 27,182 inhabitants, most of them living on poverty conditions in sparse towns and communities. The region's predominant economic activity is the extensive and transhumant breeding of goats for subsistence. There is also an incipient tourism activity related to the provincial protected areas.

The creation process of this MF took several years (it started in 2001) and was driven by the Province of Neuquén Council for Development Planning and Action (COPADE). COPADE is a subnational government agency that brings together political and technical leaders, including the governor and the heads of Science and Technology and Land Management. This agency promoted the formation of a MF as a way of improving the standard of living and especially the integration of the region's towns and rural communities. Given its integration goal, soon several local organizations joined COPADE in the management group that put together the creation project: the municipal governments of Huinga-Co, Manzano Amargo, Los Miches, El Cholar, and Andacollo, and three local organizations: Pro-Eco Foundation, Chacra-Ruca School, and Chos Malal Women Council. ${ }^{2}$

As read in the creation project, three major problems affect the MF territory: 1) high poverty level, 2) lowering of the native pasturelands' support capacity, and 3) lack of integration and communication among the sparse towns and communities. In response to those problems, the MF's creation project focuses on cultural and educational promotion, forest development, and protected areas-related tourism. Between 2007 and 2015, the MF's main activities included:

- Curi Leuvú River Basin Strategic Plan.

- Villa del Nahueve Territorial Zoning and Strategic Plan.

- Native plants' production workshop.

- Assistance to local producers for the formulation of Conservation and Sustainable Management Projects to be financed by the National Fund for the Enrichment and Conservation of Native Forests.

- Formulation of sustainable forest management projects to be funded by the PNUD within the framework of the National Program for the Protection of Native Forests.

- Several cultural and educational activities.

2 See http://www.bosquesmodelo.net/norte-de-neuquen .Visited on April 17, 2019. 


\subsection{San Pedro Model forest: Some Conflict and Societal-Driven Process}

After two failed attempts in 1997 and 2001, San Pedro MF officially formed in 2007. Located in the Northeastern province of Misiones, San Pedro woods are part of the last patches of Atlantic Tropical Forest remaining in South America. San Pedro MF's total area is 443,500 hectares, which comprises the department of San Pedro and the Yabotí Biosphere Reserve, shared between the San Pedro and the Guaraní departments. The MF also includes other minor provincial protected areas. In all, the Yabotí Biosphere Reserve and the provincial protected lands account for half of the MF area. Outside the biosphere reserve, there is an important number of fiscal lands occupied by small producers with precarious land tenures. The population living in the MF area amounts to 31,050 inhabitants, mostly low-income, small farmers and producers. There are also several aldeas (villages) of MbyáGuaraní communities, recognized by the provincial government according to the national normative. The total population of those aldeas is estimated in 500 people. The main economic activity on the FM territory is the extraction of timber that is sold to timber firms outside San Pedro. Other activities include the small-scale growing of tobacco, tea, and yerba mate, and poultry production and truck farming for local consumption.

The MF's final creation in 2007 was prompted by the mobilization of San Pedro department's neighbors and producers, which included road blockades and other forms of protest. Small local producers demanded public measures promoting forest-related activities with more added-value than the simple extraction of timber. The Province of Misiones Government responded to those demands by fostering the creation of a MF within the national MF Program. Upon the local producers' mobilization, the provincial Undersecretariat for Development and Afforestation, the San Pedro Municipal Government, and the National University of Misiones' Forestry School joined forces with local actors to create the MF.

According to the MF creation proposal, accredited by RIABM in 2007, the territory under San Pedro MF faces two major problems: 1) the degradation of forest resources and 2) the low added-value of current forest-related activities. To deal with both problems, San Pedro MF pursues the ultimate goal of attaining the environmental, social, economic, and cultural sustainability of ecosystems and communities.

San Pedro MF is run by an Executive Board (Mesa Ejecutiva) made up of six members. Four of them represent the following organizations: the provincial Under-secretariat for Development and Afforestation, San Pedro Municipal Government, National University of Misiones' Forestry School, and San Pedro's Association of Producers, Businessmen, and Professionals 
(APICOP). A fifth member represents the Mbyá-Guaraní communities and the sixth one is a representative of all stakeholders (timber, tourism, sustainable production, education, environmental impact, and monitoring). The Executive Board is in charge of formulating and deciding upon the MF projects. $^{3}$ The MF activities have focused on three programmatic lines: 1) local productive development, 2) natural resources management, and 3) education.

Between its formation and 2015, the MF's main activities included:

- Araucaria XXI project for the conservation of natural and cultural resources, funded by the Spanish Agency for International Development Cooperation (AECID).

- Yabotí Biosphere Reserve sustainable management plan, funded by the national Secretariat for the Environment and Sustainable Development (SAyDS).

- Assistance to local producers for the formulation of Conservation and Sustainable Management Projects to be financed by the National Fund for the Enrichment and Conservation of Native Forests.

- Formulation of sustainable production projects to be funded by the PNUD within the framework of the National Program for the Protection of Native Forests.

- Building of a Nursery for Native Forest Species.

- Training Course on Wood House Building.

- Native Seeds Workshop.

- Non-timber Forest Products Workshop.

- Traditional Handicrafts Workshop.

- Meetings of San Pedro Indigenous Communities.

As in the other MF, these activities have not been funded by the National Model forest Program itself but by other agencies and funds, including other programs within SAyDS.

\subsection{Tucumán Model Forest: Low Conflict and Technocratic-Driven Process}

Created in 2008, Tucumán MF is the youngest and smallest Argentine MF, even though it is the most populated one. The MF territory is set by

See https://misionesonline.net/2007/07/13/crearon-la-mesa-ejecutiva-para-avanzaren-el-programa-bosque-modelo-en-san-pedro/ .Visited on April 19, 2019. 
three river basins: Lules, North Colorado, and South Tapia; it belongs to the Yunga Forest region but it also contains a small patch of Chaqueño Forest. The MF's total area is 180,000 hectares and includes the municipalities of San Miguel de Tucumán (the provincial capital), Yerba Buena, Las Talitas, Tafí Viejo, and Lules, and the rural communes of San Pablo, Villa Nougués, Raco, El Manantial, Cebil Redondo, and San Javier. The total population of Tucumán MF is 900,000 inhabitants, most of which live in the city of San Miguel de Tucuman and its surroundings. In spite of its small size, the MF comprises a variety of landscapes running from the plains to the east to the High Andes mountains to the west; it is home to the San Javier Sierra Park (14.174 hectares), run by the National University of Tucumán. Outside de urban area, the main economic activities within the MF (and the province) are agriculture (mostly, citrus and sugar cane) and the related agro-industry. Towards the west, there is a greater presence of cattle breeding and truck farming for local consumption.

The MF creation process was prompted by Yerba Buena municipal authorities concerned with both social vulnerability and environmental degradation. By 2004, Yerba Buena authorities got in touch with the National model forest Program staff. Upon those contacts, two workshops were run between 2004 and 2006 to promote the formation of a MF in the framework of the then existing Yerba Buena Civic Forum, a participatory municipal forum created in the aftermath of the socio-economic crisis of 2001-2002. A «promoting group» came out of the second workshop, which then became the Executive Board (Mesa Ejecutiva) that put together and presented the MF creation project. This Executive Board was made up of a representative of the following organizations: Yerba Buena Municipal Government, Tucumán Foundation, Pro Yungas Foundation, Tucumán National University's Architecture and Urbanism School, Yerba Buena Civic Forum, and the Province of Tucumán's Secretariat for the Environment.

According to the creation project, the three major problems within Tucumán MF are: 1) unplanned urban growth, 2) agro-industrial contamination, and 3) deforestation and ecosystem fragmentation. To cope with these problems, the MF undertakes as its main goal the planning and management of the sustainable development and conservation of natural resources, giving special importance to territorial zoning and environmental conservation.

The main activities developed by Tucumán MF between 2008 and 2015 included:

- Formulation and execution of conservation projects funded by SAyDS.

- Formulation of territorial zoning plans. 
- Forest industry strategic plan.

- Tomato-tree production project.

- Formulation of management plans for protected areas.

- Workshops and course trainings on rural tourism and traditional handicrafts.

- Workshops and course trainings on environmental education.

- Workshop on technical capacities for indigenous communities.

- Formulation of projects to be funded by the PNUD within the framework of the National Program for the Protection of Native Forests.

- Yerba Buena ecological exchange program (recyclable materials for ornamental plants).

\section{Some Lessons Learned and Tentative Conclusions}

Twenty years after the adoption of the model forest concept in Argentina, evidence shows it is a useful policy implementation tool at the local level. Model forests allow for enhanced multilevel coordination, thus providing a platform for plans and projects on sustainable forestry and sustainable livelihoods. Multisectoral governance structures enable dialogue spaces contributing to the management of conflicts arising from conflicting perspectives on land management and divergent interests. These dialogue spaces also allow for the participatory construction of a shared vision and strategic planning at forest landscape scale. Incentives and support for sustainable forest management are integrated with other policy instruments for production diversification and social assistance aimed at social inclusion and the improvement of the life quality and standard of traditionally marginalized forest dependent local communities.

It must be noted that not all the initiatives result in a new model forest. Some initiatives fail due to some of these causes:

- Expecting the creating of a model forest to be a fast access to external donors and funding;

- Confusing a model forest with a template for the creation of non-governmental organizations that executes projects selected by the small group that created it;

- Insufficient social capital, thus failing to produce a participatory governance structure;

- Radical political changes and/or lack of political support from provincial and/or local authorities; 
- Lack of minimum resources to operate, revealing the lack of commitment of the promoting partners, and rendering the initiative unsustainable.

The formation of a model forest demands time, usually not less than two to three years. The process involves, inter alia, the mediation of conflicts so that stakeholders with divergent visions get involved in the model forest governance. Should this not be achieved, the model forest might risk turning into a restricted group thus failing to meet the principles underlying this concept. In addition, existing levels of conflict shape the adoption and implementation process of transnational concepts like MF. We find that when there are fewer societal demands and protests, the adoption process is more technocratic-driven. When stakeholders' pressure and political mobilization increases, the process becomes more socially-driven.

The transaction costs involved in the process of developing a model forest are higher than those associated with the implementation of top-down initiatives. However, there are positive outcomes related to the development of social capital, strengthening of local capacity and improvement of the quality of life of local communities in harmony with the sustainability of forest ecosystems. Thus, model forests are useful tools for the enhancement of local forest culture.

Like other participatory governance initiatives, model forests are susceptible to cooptation by groups of interest. The active presence of provincial and local public sector is critical in maintaining balance and ensuring that all stakeholders may dialogue on a leveled playfield, especially vulnerable actors. Public sector presence is also important in order to foster inclusive development of marginalized communities and avoid the appropriation of the benefits by local elites.

The academia has a relevant role in Argentine model forests providing technical support and extension for local initiatives. Academic organizations contribute experience in order to incorporate best practices for SFM and productive innovation. This support targets small farmers and indigenous communities that receive advice to optimize their productive activities and harmonize them with the carrying capacity of their land.

Forests generate critical ecosystem services, such as landscape, biodiversity, and water security. We thus sought to look inside communitymanaged forests to see how ecosystem services are generated, and also outside these community, to analyze how varying contexts affect that generation of environmental benefits. We expect the quality of ecosystem services to be contingent on the adoption, implementation, and governance structure of forest communities. By identifying the adoption and implementa- 
tion process of MF, our study can help improve the effectiveness of public policy aimed at supporting community stewardship of forests. We believe our research on MF in Argentina will benefit not just policy-makers, but as importantly, community groups and other stakeholders.

\section{References}

Agrawal, A. and Chhatre, A. (2006). Explaining success on the commons: Community forest governance in the Indian Himalaya. World Development, 34(1), 149166.

Alcañiz, I. (2016). Environmental and Nuclear Networks in the Global South: How Skills Shape International Cooperation. New York: Cambridge University Press.

Andonova, L.B., Betsill, M.M. and Bulkeley, H. (2009). Transnational climate governance. Global environmental politics, 9(2), 52-73.

Berardo, R. and Mazzalay, V. (2012). Confianza, influencia política e intercambio de recursos en arenas decisorias regionales. Revista de Ciencia Política 32(2), 479500.

Campos Arce, J.J., Finegan, B. and Villalobos Soto, R. (2001). Management of goods and services from neotropical forest biodiversity: diversified forest management in Mesoamerica. CBD Technical Series 3, 5-16.

Carpenter, D. (2001). The Forging of Bureaucratic Autonomy: Reputations, Networks, and Policy Innovation in Executive Agencies 1862-1928. Princeton: Princeton University Press.

FAO, (2005). Evaluación de los Recursos Forestales Mundiales 2005 - Argentina Informe Nacional. Departamento Forestal, Organización de las Naciones Unidas para la Agricultura y la Alimentación, Roma, Italia.

Gabay, M. and Alam, M. (2017). Community forestry and its mitigation potential in the Anthropocene era: the importance of land tenure governance and the threat of privatization. Forest Policy E Economics 79, 26-35.

Gibson, C.C., McKean, M.A. and Ostrom, E. (Eds.) (2000). People and Forests: Communities, Institutions, and Governance. Cambridge: MIT Press.

Haas, Peter M. (1992). Introduction: epistemic communities and international policy coordination. International organization 46(1), 1-35.

Hadden, J. (2015). Networks in contention. New York: Cambridge University Press.

Hadden, J. and Seybert, L.A. (2016). What's in a Norm? Mapping the Norm Definition Process in the Debate on Sustainable Development. Global Governance: A Review of Multilateralism and International Organizations, 22(2), 249-268.

Heclo, H. (1978). Issue Networks and the Executive Establishment. In the New

Hochstetler, K. and Keck, M.E. (2007). Greening Brazil: Environmental activism in state and society. Duke University Press. 
Keck, M.E. and Sikkink, K. (1999). Transnational advocacy networks in international and regional politics. International Social Science Journal, 51(159), 89-101.

Lubell, M. (2007). Familiarity breeds trust: Collective action in a policy domain. Journal of Politics 69(1), 237-250.

McCarthy, J. (2006). Neoliberalism and the politics of alternatives: Community forestry in British Columbia and the United States. Annals of the Association of American Geographers, 96(1), 84-104.

Naysmith, J. (2003). Canada's Model Forest Program - Building on Success. Paper submitted to the XII World Forestry Congress, Québec, Canada.

Nygren, A. (2005). Community-based forest management within the context of institutional decentralization in Honduras. World Development, 33(4), 639-655.

Pagdee, A., Kim, Y.S. and Daugherty, P.J. (2006). What makes community forest management successful: A meta-study from community forests throughout the world. Society and Natural Resources, 19(1), 33-52.

Perez-Verdin, G., Kim, Y.S., Hospodarsky, D. and Tecle, A. (2009). Factors driving deforestation in common-pool resources in northern Mexico.Journal of environmental management, 90(1), 331-340.

Political System, ed. A. King. Washington D.C.: The American Enterprise Institute for Public Policy Research.

Sabatier, P. A. and Jenkins-Smith, H.C. (1999). The Advocacy Coalition Framework: An Assessment. In Theories of Policy Process, Ed. P. A. Sabatier. Boulder: Westview Press.

SAyDS, (2016). Programa Nacional de Bosques Modelos - Red Nacional de Bosques Modelos - Anuario 2015. Secretaría de Ambiente y Desarrollo Sustentable, Buenos Aires, Argentina.

Schneider, M., Scholz, J., Lubell M., Mindruta D., and Edwardson, M. (2003). Building consensual institutions: Networks and the national estuary program. American Journal of Political Science 47(1), 143-158.

Scholz, J. T., Berardo, R., and Kile B. (2008). Do networks solve collective action problems? Credibility, search, and collaboration.» Journal of Politics 70(2), 393406.

SRIBM/SRNyAH-DB/PRODIA, (1996). Informe del Primer Taller para la Red de Bosques Modelo en la República Argentina, Secretaría Internacional de Bosques Modelo, Secretaría de Recursos Naturales y Ambiente Humano, Buenos Aires, Argentina.

Terborgh, J. and Peres, C.A. (2017). Do community-managed forests work? A biodiversity perspective. Land, 6(2), 22. 


\section{Keywords}

forest governance - environmental conservation - transnational networks norm adoption

\section{Palabras clave}

gobernanza forestal - conservación ambiental - redes transnacionales adopción de normas

\section{Resumen}

¿Cómo son adoptadas localmente las ideas ambientales transnacionales? Respondemos esta pregunta mediante el examen de la adopción y el desarrollo de la idea de bosque modelo en Argentina desde la segunda parte de los años 1990. El concepto de bosque modelo nació en Canadá en 1991 como la etiqueta de un nuevo programa nacional orientado a promover la construcción de procesos y arreglos de gobernanza para el manejo sostenible de bosques en el nivel local. La idea pronto comenzó a viajar a través del mundo gracias a las iniciativas de las agencias canadienses de cooperación internacional y se convirtió en una referencia de programas de las Naciones Unidas. Argentina fue una adoptante temprana de la idea de bosque modelo: en 1996 la secretaría ambiental nacional firmó una carta de intención con la Red Internacional de Bosques Modelo y comenzó a aplicar la idea en distintos puntos del país. Como resultado, seis bosques modelos se formaron a lo largo del país entre 1998 y 2008. Argumentamos que las redes transnacionales de burócratas, promotores e interesados directos ayudan a entender cómo los programas de gobernanza de recursos naturales viajan a través de los países. En función de los niveles de conflicto existentes en los lugares de adopción, distinguimos dos tipos de adopciones: aquellas más impulsadas técnicamente y aquellas impulsadas socialmente. Esperamos que las adopciones impulsadas técnicamente tendrán lugar en contextos de menores niveles de conflicto y las adopciones impulsadas socialmente en contextos de mayores niveles de conflicto. Este trabajo constituye un primer paso de un proyecto más amplio que busca comparar la adopción y evolución de bosques comunitarios en América Latina. 